\title{
COL18A1 Gene Product
}

National Cancer Institute

\section{Source}

National Cancer Institute. COL18A1 Gene Product. NCI Thesaurus. Code C124854.

A protein encoded by the COL18A1 gene. 